\title{
Evaluasi Kinerja Usaha Petani Garam Rakyat di Kabupaten Bima, Nusa Tenggara Barat
}

\author{
Performance Evaluation of Salt Farmers Business People \\ in Bima Distric, Nusa Tenggara Barat Province
}

Amril Rahman*1, Sapta Raharja ${ }^{* 2}$, dan Darwin Kadarisman ${ }^{* 3}$

${ }^{1}$ Kementerian Kelautan dan Perikanan

Gd. Mina Bahari III lt. 3 Jl. Medan Merdeka Timur No. 16, Jakarta Pusat 10110

${ }^{2}$ Departemen Teknologi Industri Pertanian, Fakultas Teknologi Pertanian, Institut Pertanian Bogor 32Departemen Ilmu dan Teknologi Pangan, Fakultas Teknologi Pertanian, Institut Pertanian Bogor "Jl. Kamper, Kampus IPB Darmaga, Bogor 16680

\begin{abstract}
ABSTRAK
Banjir impor garam dari negara empat musim untuk memenuhi kebutuhan konsumsi dan kebutuhan industri ke Indonesia membuat harga garam rendah. Air laut tropis yang kaya dan sinar matahari dengan garis pantai terpanjang keempat di dunia, tetapi pada tahun 2010 produksinya hanya 30.600 ton garam atau kurang dari $1 \%$ dari kebutuhan nasional, karena panen di sejumlah pusat produksi 1,000-7,000 ton. Area kolam salah satu faktor yang memengaruhi produksi garam merupakan bagian integral dari kinerja produksi produsen garam nasional. Kinerja bisnis pada petani garam rakyat dianalisis atas pengaruh luas lahan tambak pada produktivitas, mutu dan kinerja keuangan dengan analisis varians (Anova atau analysis of varians), untuk mutu dilakukan tes laboratorium dan analisis kinerja keuangan dengan menggunakan perhitungan pendapatan, Revenue/Cost (R/C) ratio dan Benefit/Cost (B/C) ratio. Hasil analisis menunjukkan keragaman produktivitas tidak nyata. Keragaman salinitas air laut tertinggi pada orang-orang yang memproduksi garam dengan luas 0,23 hektar lahan dengan rataan 4.576.666,67, skor terendah pada kelompok flat garam petani dengan luas 0,85 hektar lahan dengan rataan 1.677.500. Hasil analisis menunjukkan keragaman pendapatan tidak nyata. $\mathrm{R} / \mathrm{C}$ ratio dan $\mathrm{B} / \mathrm{C}$ ratio yang dihasilkan memberikan nilai tertinggi pada kelompok orang yang memproduksi dataran garam seluas 0,23 hektar dengan rataan 10,1533, terendah pada kelompok petani garam dengan luas lahan rataan dari 0,85 hektar dengan rataan 3,2367. Pengaruh garam tambak lahan produktivitas, kualitas dan kinerja keuangan Hasil analisis menunjukkan analisis varians tidak adanya perbedaan yang nyata, maka kinerja usaha rakyat petani garam dinilai rendah dan perlu ditingkatkan oleh petani garam.
\end{abstract}

Kata kunci: evaluasi, kinerja usaha, luas lahan, produktivitas, mutu, petani garam

\section{ABSTRACT}

Flood of salt imports from the country four season to meet consumption needs and the needs of industry to Indonesia make the price of salt is low. Surprisingly rich tropical sea water and sunlight with the fourth longest coastline in the world's, but in 2010 national production of only 30,600 tons of salt or less than $1 \%$ of national demand, because the harvest in a number of production centers 1.000-7.000 tons. Ponds area and one of the factors that influence the production of salt is an integral part of the performance of producing salt as salt producers nationwide. Business performance on a salt farmer folk analyzed the influence of the land area of salt ponds on productivity, quality and financial performance by analysis of variance (Anova), for quality is conducted lab tests and analysis of financial performance using the calculation of revenue, $\mathrm{R} / \mathrm{C}$ ratio and $\mathrm{B} / \mathrm{C}$ ratio. The analysis showed no real productivity diversity. Salinity of sea water highest diversity in the people who produce the salt flats with an area of 0.23 acres of land with an average 4,576,666.67, the lowest score in the group of farmers with vast salt flat

\footnotetext{
*) Korespondensi:

Gd. Mina Bahari III lt. 13 Jl. Medan Merdeka Timur No.16, Jakarta Pusat 10110; e-mail: amril04januari08@yahoo.co.id
} 
0.85 acres of land with an average 1.6775 million. The analysis showed no real income diversity. R / C ratio and $\mathrm{B} / \mathrm{C}$ ratio is generated providing the highest value in the group of people who produce salt area of 0.23 hectares with an average 10.1533, the lowest in the group of salt peasants with land area of 0.85 acres with a mean average of 3.2367. Effect of salt ponds land productivity, quality and financial performance analysis of variance analysis showed no significant difference, then the people's business performance by producing salt undervalued and needs to be increased by salt farmers.

Key words: evaluation, business performance, land area, productivity, quality, salt farmers

\section{PENDAHULUAN}

Pembuatan garam di Indonesia umumnya menggunakan sistem penguapan air laut dengan memanfaatkan sinar matahari (Solar Evaporation) di atas lahan tanah, berarti pembuatan garam harus dekat dengan pantai. Namun beberapa daerah yang memproduksi garam dengan cara memasak, karena kondisi tanah yang porous, yaitu Propinsi Nangroe Aceh Darussalam (NAD) dan Bali, dimana dilakukan dengan cara memasak. Kebutuhan terhadap garam tidak dapat digantikan, setiap orang mengkonsumsi lebih kurang $4 \mathrm{~kg}$ garam per tahun dalam bentuk aneka pangan (KKP, 2010). Masa panen garam normal di Indonesia umumnya sekitar 4-5 bulan, yaitu dimulai sejak bulan Juli-November.

Berdasarkan data dari PT Garam (persero) tahun 2010, kebutuhan garam di dalam negeri mencapai 2.872.326 ton, terdiri dari kebutuhan garam industri CAP (Chlor Alkali Plant) 1.519.440 ton, dan garam untuk non CAP 1.352. 886 ton. Angka ini diperkirakan akan meningkat seiring dengan bertambahnya jumlah penduduk dan berkembangnya industri yang membutuhkan garam. Namun cuaca ekstrem yang melanda Indonesia di tahun 2010 berdampak serius terhadap produksi garam secara nasional.

Kementerian Perindustrian memastikan, produksi garam tahun 2010 hanya 30.600 ton atau sekitar 1\% dari kebutuhan nasional tahun 2010 akibat panen di sejumlah sentra produksi 1.0007.000 ton. Padahal di tahun 2009, berdasarkan data Kementerian Kelautan dan Perikanan, kemampuan produksi garam dalam negeri yang dihasilkan dari petani/usaha kecil/menengah garam, mencapai 1.200 .000 ton atau sekitar $42 \%$ dari kebutuhan nasional di tahun 2010. Hal ini mengakibatkan Indonesia masih sangat membutuhkan impor garam dari luar negeri. Pada tahun 2010, pemerintah mengimpor garam 2,2 juta ton dari Australia (80\%), India (15\%), dan China (3\%) dan sisanya dari berbagai negara lain (KKP, 2010).

Negara Indonesia yang sebagian besar daerahnya berada di daerah tropis yang langsung dipengaruhi oleh garis khatulistiwa, memotong Indonesia hampir menjadi dua dan luas lautnya mencapai 5,8 juta kilometer persegi atau $70 \%$ dari luas seluruh Indonesia, memiliki ribuan pulaupulau kecil dan salah satu negara yang memiliki pantai terpanjang di dunia menjadi ironis sebagai negara pengimpor garam.

Di tengah potensi kekayaan sumber daya lautan Indonesia, garam salah satu produk yang mempunyai kontribusi dalam proses pembangunan ekonomi ternyata belum mampu mengangkat para petani garam dari garis kemiskinan. Meskipun di lain sisi dipahami bahwa kemiskinan petani garam juga disebabkan oleh faktor lain, yaitu kondisi alam yang tak menentu, kebijakan yang diterapkan pemerintah dan rendahnya kinerja petani garam, terutama dapat dilihat dari aspek (1) rendahnya tingkat perhitungan keuangan usaha petani garam dalam menentukan keuntungan dengan membandingkan antara hasil yang diharapkan akan diterima pada waktu panen (penerimaan, revenue) dengan biaya (cost) yang harus dikeluarkannya, walaupun tidak harus secara tertulis; (2) rendahnya produktivitasnya usaha petani garam dan mutu produk garam.

Berdasarkan hal di atas, maka dari satu sisi sangat dibutuhkan adanya penguatan manajemen untuk meningkatkan kinerja dan di sisi lain pelaksanaan manajemen kinerja untuk mengevaluasi kinerja yang dimaksudkan dengan mengetahui tingkat pencapaian sasaran petani garam, terutama untuk mengetahui penyimpangan supaya segera diperbaiki, sehingga sasaran atau tujuan dapat tercapai. Tujuan kajian (1) Menganalisis kinerja finansial (Pd dan R/C ratio) usaha petani garam rakyat, dan (2) Menganalisis kinerja non finansial (produktivitas dan mutu) usaha petani garam rakyat.

\section{METODOLOGI}

Kajian dilaksanakan di Desa Donggobolo Kecamatan Woha dan Desa Bontokape Kecamatan Bolo Kabupaten Bima, Propinsi Nusa Tenggara 
Barat, Kabupaten bima terletak pada 118 $44^{\prime \prime}$ 119²2" Bujur Timur dan 0808'-0857" Lintang Selatan. Kabupaten Bima berada pada bagian paling timur Pulau Sumbawa, diapit oleh Kabupaten Dompu disebelah Barat, Provinsi Nusa Tenggara Timur di sebelah Timur, dan Laut Flores disebelah Utara serta Samudera Indonesia di sebelah Selatan.

Kajian menggunakan metode penelitian kuantitatif. Data yang dikumpulkan terdiri dari data primer dan sekunder. Penelitian dilakukan melalui beberapa tahapan berikut: (1) penetapan lokasi; (2) pengumpulan data primer dan sekunder; (3) penabulasian data; dan (4) pengolahan atau analisis data.

Pengumpulan data di lapangan digunakan metode studi kasus, karena daerah penelitian cukup luas. Pada metode studi kasus tidak semua individu di dalam populasi diamati, melainkan hanya suatu fraksi (bagian) dari populasi yang disebut sebagai contoh. Proses penetapan contoh (agar hasil yang dicapai baik dan paling tidak mendekati kebenaran), dengan metode metode pengambilan contoh acak distratifikasi (stratified random sampling) (Moehar, 2005). Di dalam stratified random sampling, pengambilan contoh langsung secara acak dari obyeknya hanya cocok/ tepat untuk suatu kelompok data homogen atau relatif homogen, maka unsur yang diambil tidak perlu terlalu banyak (Supranto, 2002).

Kriteria penetapan strata pada penelitian ini didasarkan luas lahan produksi garam rakyat, yaitu membagi populasi menjadi tiga sub populasi, yaitu kelompok petani garam besar ( $\left.\mathrm{n}_{1}\right)$, kelompok petani garam menengah (n2) dan kelompok petani garam kecil (n3). Untuk masingmasing kelompok diambil lima responden secara acak.

Data primer untuk mengetahui pengeluaran, penerimaan/pendapatan usaha petani garam, faktor produksi, hasil produksi dan apakah perbedaan tipologi petani garam rakyat yang ada di Kabupaten Bima terhadap pendapatan petani garam rakyat berasal dari luas lahan yang dimiliki. Untuk mendapatkan data ini dilakukan wawancara, penyebaran kuesioner dan observasi. Data sekunder diperoleh dari berbagai literatur maupun referensi yang terkait dengan tujuan dan sasaran penelitian, seperti laporan dan penelitian terdahulu mengenai usaha petani garam rakyat, dari sejumlah dinas dan instansi pemerintah seperti Kantor Statistik, Dinas Kelautan dan Perikanan, dan lain-lain.
Pengaruh luas lahan petani garam rakyat yang ada di Kabupaten Bima terhadap produktivitas, mutu dan kinerja finansial dilakukan analisis keragaman (Analysis of variance atau ANOVA), sebelum data diolah dilakukan uji homogenitas data dengan bantuan software Statistical Package for Social Science (SPSS). Hipotesis yang diajukan sebagai berikut:

a. Produktivitas

Ho : tidak terdapat perbedaan produktivitas pada luas lahan berbeda

$\mathrm{Ha}$ : terdapat perbedaan produktivitas pada luas lahan berbeda

b. Mutu

Ho : tidak terdapat perbedaan \% Kadar Garam per $10 \mathrm{ml}$ air laut pada luas lahan berbeda

$\mathrm{Ha}$ : terdapat perbedaan \% Kadar Garam per $10 \mathrm{ml}$ air laut pada luas lahan berbeda

c. Pendapatan

Ho : tidak terdapat perbedaan pendapatan pada luas lahan yang berbeda

Ha : terdapat perbedaan pendapatan pada luas lahan berbeda

d. $\mathrm{R} / \mathrm{C}$ ratio

Ho : tidak terdapat perbedaan $\mathrm{R} / \mathrm{C}$ ratio pada luas lahan yang berbeda

$\mathrm{Ha}$ : terdapat perbedaan $\mathrm{R} / \mathrm{C}$ ratio pada luas lahan berbeda

\section{Pengamatan dan Pengukuran}

a. Pendapatan per Ha usaha petani garam rakyat

Pendapatan usaha petani garam merupakan selisih antara total penerimaan dan total biaya, maka usaha petani garam dapat dirumuskan berikut:

$$
\begin{aligned}
\mathrm{Pd}= & \mathrm{TR}-\mathrm{TC} \\
\mathrm{TR} & =\mathrm{Y} . \mathrm{Py} \\
& \mathrm{TC}=\mathrm{FC}+\mathrm{VC}
\end{aligned}
$$

Dimana :

Pd : pendapatan usaha

TR : total penerimaan

TC : total biaya

FC : biaya tetap

VC : biaya variabel

Y : produksi yang diperoleh dalam suatu usaha

Py : harga $\mathrm{Y}$

b. $\mathrm{R} / \mathrm{C}$ ratio

Analisis Return Cost (R/C) ratio merupakan perbandingan (ratio atau nisbah) antara penerimaan (revenue) dan biaya (cost). 
Pernyataan tersebut dapat dinyatakan dalam rumus berikut:

$$
\begin{gathered}
A=R / C \\
P y \times Y \\
F C+V C
\end{gathered}
$$

Dimana:

$$
\begin{array}{ll}
\text { A } & \text { : R/C ratio } \\
\mathrm{R} & \text { : penerimaan }(\text { revenue) } \\
\mathrm{C} & \text { : biaya (cost) } \\
\mathrm{Py} & \text { : harga output } \\
\mathrm{Y} & \text { : output } \\
\mathrm{FC} & \text { : biaya tetap (fixed cost) } \\
\mathrm{VC} & \text { : biaya variabel (variabel cost) }
\end{array}
$$

Kriteria keputusan:

$\mathrm{R} / \mathrm{C}>1$, usaha petani garam untung

$\mathrm{R} / \mathrm{C}<1$, usaha petani garam rugi

$\mathrm{R} / \mathrm{C}=1$, usaha petani garam impas (tidak untung/tidak rugi)

c. Pengukuran produktivitas usaha petani garam rakyat

Ukuran produktivitas usaha petani garam rakyat dihitung dengan rumus berikut:

$$
\text { Produktivitas }=\frac{\text { Produksi (Ton) }}{\text { Luas Lahan }(\mathrm{Ha})} \text { Ton } / \mathrm{Ha}
$$

Produksi dalam Ton

Luas Lahan dalan Ha

d. Pengukuran mutu produk garam rakyat

Mutu garam rakyat pada kajian ini ditentukan oleh:

- Kadar garam air laut

- Kadar $\mathrm{NaCl}(\%)$

- Warna butiran garam (visual)

- Diameter kristal (visual)

\section{HASIL DAN PEMBAHASAN}

Kabupaten Bima terdiri dari 177 desa, dimana ada 35 desa pesisir, yaitu desa yang berada di pinggir laut. Sementara 142 desa lainnya berada di wilayah lembah atau pegunungan. Luas wilayah Kabupaten Bima adalah 4.374,65 km² yang terdiri dari 7,22\% lahan sawah dan 92,78\% bukan lahan sawah.

Keadaan iklim Kabupaten Bima pada Bulan April-Juli di tahun 2011 secara rataan di tampilkan pada Tabel 1. Tabel 1 menggambarkan curah hujan di bulan April sampai dengan Juli tahun 2011 terlihat adanya penurunan secara rataan dari $235,8 \mathrm{~mm}$ per bulan menjadi $0,5 \mathrm{~mm}$ per bulan dengan hari hujan dari 21 hari per bulan turun menjadi 3 hari per bulan, sedangkan suhu udara sampai dengan bulan Juli rataannya 25,1, dengan kisaran 20,7 $\mathrm{C}$ hingga $31,7^{\circ} \mathrm{C}$.

Prakiraan curah hujan di Kabupaten Bima pada bulan Agustus sampai dengan bulan Oktober di tahun 2011 masih sangat rendah atau sama dengan pada bulan Juni dan Juli 2011,di bandingkan pada tahun 2010 yang curah hujannya di atas batas atas normal menurut data normal curah hujan bulanan yang dikeluarkan oleh Stasiun Meteorologi M. Salahuddin Bima.

\begin{tabular}{|c|c|c|c|c|c|c|c|c|c|c|}
\hline No. & Bulan & & $\begin{array}{l}\text { Suhu }^{\circ} \mathrm{C} \\
\text { (rataan) }\end{array}$ & & $\begin{array}{c}\text { Curah } \\
\text { hujan } \\
\text { ditakar } \\
(\mathrm{mm} / \mathrm{hh})\end{array}$ & $\begin{array}{l}\text { Penyi- } \\
\text { naran } \\
\text { Mata- } \\
\text { hari \% }\end{array}$ & $\begin{array}{c}\text { Tekan- } \\
\text { an } \\
\text { udara } \\
\text { (rataan) }\end{array}$ & $\begin{array}{c}\text { Kelem- } \\
\text { bapan } \\
\text { relatif \% } \\
\text { (rataan) }\end{array}$ & $\begin{array}{l}\text { Kecepat- } \\
\text { an angin } \\
\text { (rataan) } \\
(\mathrm{km} / \mathrm{jam})\end{array}$ & $\begin{array}{c}\text { Arah } \\
\text { angin } \\
\text { (rataan) }\end{array}$ \\
\hline & & 07,00 & 13,00 & 18,00 & Jam 08.00 & $\begin{array}{c}08.00- \\
16.00\end{array}$ & & 13,00 & & \\
\hline 1 & APRIL & 24,6 & 30,2 & 26,9 & $235,8 / 21$ & 49 & 1009,1 & 72 & 12,96 & 180 \\
\hline 2 & MEI & 23,7 & 31,4 & 27,0 & $34,9 / 9$ & 81 & 1009,9 & 63 & 12,96 & 180 \\
\hline 3 & JUNI & 21,3 & 30,2 & 25,5 & - & 92 & 1011,0 & 56 & 16,67 & 180 \\
\hline 4 & JULI & 21,7 & 31,00 & 26,1 & $0,5 / 3$ & 72 & 1011,2 & 56 & 16,67 & 180 \\
\hline
\end{tabular}

Data curah hujan bulanan tahun 2010 terlihat pada Tabel 2 dan batasan normal yang menunjukan curah hujan bulanan tahun 20012010 terlihat pada Gambar 1. Tabel 2 menunjukkan terjadinya curah hujan di wilayah Kabupaten Bima sejak awal Juli 2010 hingga akhir Desember 2010 di atas batas normal berdasarkan data normal curah hujan bulanan tahun 2001-2010 yang terjadi di Indonesia (Gambar 1).

Tabel 1. Data klimatologi Kabupaten Bima bulan April-Juli Tahun 2011 
Tabel 2. Data curah hujan bulanan Tahun 2010 Kabupaten Bima

\begin{tabular}{lcccccccccccc}
\hline \multirow{2}{*}{ Tahun } & \multirow{10}{c}{ JAN } & FEB & MAR & APR & MAY & JUN & JUL & $\begin{array}{c}\text { AU } \\
\text { G }\end{array}$ & SEPT & OCT & NOV & DES \\
\hline \multirow{2}{*}{2010} & 245,9 & 105,7 & 103,4 & 28 & 130 & 2,8 & 69,9 & 11 & 136,1 & 96,4 & 293,6 & 228,7 \\
\hline
\end{tabular}

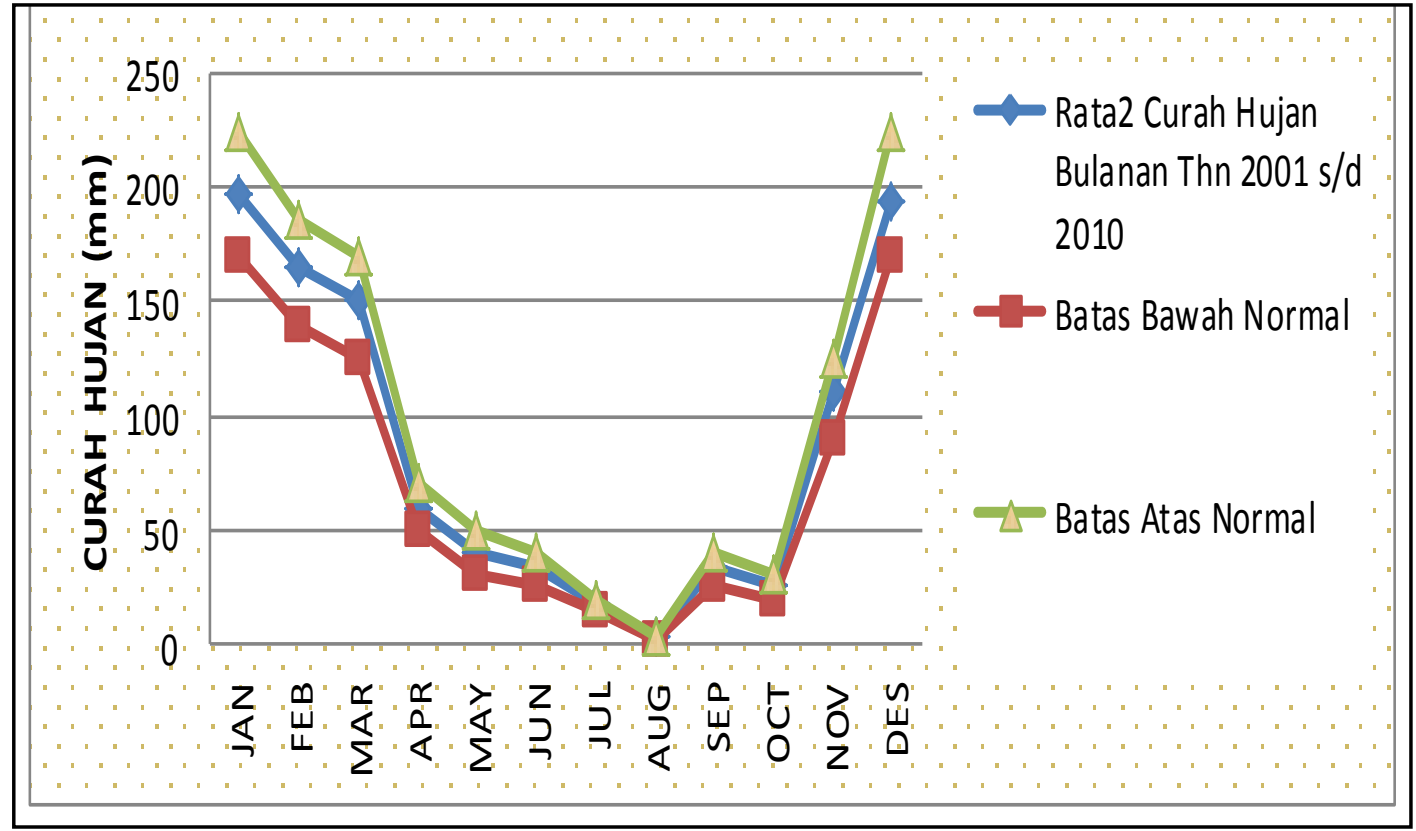

Sumber: Stasiun Meteorologi Sultan M. Salahuddin Bima, 2011.

Gambar 1. Curah hujan bulanan Tahun 2001-2010

Batas atas normal curah hujan di Indonesia bulan Juli $10 \mathrm{~mm}$ per hari, Agustus $5 \mathrm{~mm}$ per hari, September $20 \mathrm{~mm}$ per hari, Oktober $15 \mathrm{~mm}$ per hari, November $90 \mathrm{~mm}$ per hari dan Desember $165 \mathrm{~mm}$ per hari. Curah hujan di Kabupaten Bima bulan Juli, yaitu 69,9 mm per hari, Agustus $11 \mathrm{~mm}$ per hari, September 136,1 $\mathrm{mm}$ per hari, Oktober 96,4 mm per hari, November 293,6 mm per hari dan Desember 228,7 mm per hari. Ini berarti bila dibandingkan dengan data normal curah hujan di Indonesia, maka hampir sebagian besar wilayah Kabupaten Bima di bulan Juli-Desember curah hujannya di atas batas normal atau mengalami curah hujan dengan frekuensi tinggi.

Ribuan hektar lahan garam yang bergandengan dengan tambak-tambak bandeng ini sejak tahun 1950-an sudah dimanfaatkan. Usaha garam rakyat paling produktif yang ada di Kabupaten Bima meliputi dua Kecamatan, yakni Kecamatan Bolo dan Woha, memiliki lahan dengan tingkat kemiringan 0-2\%, 3-15\%, 16-40\%, dan lebih besar dari $40 \%$. Tingkat kemiringan $>40 \%$ dari luas wilayahnya terbanyak di Kecamatan Bolo, yaitu
9.557 Ha, sedangkan di Kecamatan Woha hanya $2.716 \mathrm{Ha}$.

Kecamatan Bolo dan Woha memiliki jumlah penduduk terbanyak kedua dan ketiga yang ada di Kabupaten Bima. Proporsi pemanfaatan potensi tenaga kerja terbesar di Desa Bontokape dan Desa Donggobolo berada di sektor pertanian, sektor jasa, sektor perdagangan, sektor perikanan dan sektor industri kecil, di sektor industri kecil salah satunya pada usaha garam rakyat. Luas kepemilikan lahan garam di dua desa ini rataan per orang 0,20-1,00 Ha dengan pemilik lahan terdiri dari para pegawai negeri, warga sekitar dan pengusaha. Dalam satu musim panen, bila iklim mendukung, rataan para petani garam bisa mendapatkan kurang lebih 10-15 ton garam kasar.

Teknologi yang diterapkan oleh petani garam di Desa Bontokape dan Desa Donggobolo dalam memproduksi garam, masih sangat sederhana, yaitu menggunakannya petak-petak kecil maupun berukuran sedang secara berhubungan dengan sistem air mengalir dari petak pertama ke 
petak berikutnya. Pembuatan petak-petak kecil dimaksudkan agar terjadi evaporasi/penguapan secara berulang kali. Air laut di alirkan ke kolam pengumpul/pengendapan dengan menggunakan kincir angin dan bila tidak ada angin menggunakan gajo (ember).

Harga garam di Kabupaten Bima cenderung bervariasi dipengaruhi oleh cuaca dan musim garam. Di tahun 2011 harga garam tertinggi Rp120.000-Rp150.000 per karung (isi 50 $\mathrm{kg}$ ) dan Rp70.000-Rp90.000 per karung isi $50 \mathrm{~kg}$ terjadi di awal musim, yaitu satu atau dua bulan pertama pada saat para petani garam hanya memiliki sedikit garam hasil panen awal. Kemudian harga merangkak turun menuju harga terendah, yaitu Rp3.000-Rp5.000 per karung isi 50 $\mathrm{kg}$ atau Rp60-Rp100 per kg, terjadi di pertengahan hingga akhir musim pada saat garam sudah sangat banyak ditingkat petani garam atau pada saat panen raya.

Harga yang tinggi di awal musim hanya bisa dinikmati sesaat oleh sebagian petani garam yang sudah sangat siap dalam menyiapkan lahan produksinya sebelum musim kemarau tiba, di antaranya memperbaiki kembali semua saluran, membentuk kembali kolam-kolam pemekatan, pengkristalan, tanggul-tanggul, memperbaiki dasar tanah, membersihkan lahan dari lumpur dan kotoran-kotoran kolam-kolam kristalisasi, persiapan penempatan kembali mesin pompa air (jika diperlukan), kincir angin, dan lain sebagainya. Harga yang tinggi di awal musim tidak bisa dinikmati oleh petani garam yang belum siap menghadapi musim kemarau. Salah satu penyebabnya adalah kondisi lahan garam yang masih dijadikan lahan tambak ikan bandeng (uta londe), dikarenakan petani garam di Desa Bontokape dan Desa Donggo ada yang menggunakan sistem polikultur pada lahan tambaknya, dimana pada saat musim penghujan lahan yang ada dijadikan tambak ikan bandeng (uta londe) dan pada saat kemarau lahan dijadikan tambak garam dalam upaya peningkatan pendapatan.

Saat panen raya, harga garam yang berlaku di tingkat petani tidak memberi insentif bagi petani garam. Dari kenyataan tersebut mengakibatkan tingkat pendapatan petani garam senantiasa masih rendah. Konsekuensi dari pendapatan yang rendah, para petani garam rakyat tersebut tidak memiliki cadangan dana untuk melakukan investasi terhadap lahan garam yang dimiliki guna meningkatkan produktivitas maupun mutu garam, sehingga dapat dikatakan harga bagi petani garam merupakan sebagai perwujudan produktivitas dan mutu. Konsekuensi yang lebih jauh lagi adalah pertambahan penduduk menyebabkan lahan garam semakin menyempit dan perkembangan ekonomi, semakin lama semakin besar tingkat kebutuhan hidup untuk beberapa tahun mendatang. Peningkatan produksi garam dapat pula dilakukan dengan membuat suatu kebijakan terkait dengan pertanahan, yaitu konsolidasi tanah, perlindungan tata ruang dan redistribusi tanah yang dapat digunakan untuk usaha garam terutama bagi petani penggarap garam (Ihsannudin, 2012).

Secara umum, petani garam rakyat di dua desa ini sangat mengharapkan adanya pabrikpabrik baru yang menangani garam tumbuh di Kabupaten Bima, khususnya berada di Kecamatan Woha maupun Kecamatan Bolo, sehingga para petani garam bisa langsung menjual hasil garamnya ke pabrik garam tanpa harus melalui pedagang pengumpul maupun pedagang garam yang membeli dengan harga rendah. Sampai saat ini perusahaan yang membeli garam dari petani garam di Kabupaten Bima hanya satu perusahaan, yaitu PD Budiono Madura, sehingga peluang memonopoli harga garam sangat terbuka lebar.

PD Budiono Madura datang membeli garam hanya pada waktu panen raya terjadi, pada saat harga garam di tingkat petani garam rendah, sehingga petani garam terpaksa menjualnya karena takut garamnya kembali mencair. Namun ada juga petani garam di Desa Bontokape maupun Desa Donggobolo yang bertahan menyimpan garamnya, karena berharap harga garam di tingkat petani garam membaik. Namun, menurut Haryatno (2012), penimbunan pada usaha garam merupakan suatu strategi yang dapat dilakukan untuk menjaga kelangsungan usaha sekaligus menjaga kebutuhan garam di pasaran.

\section{Karakteristik petani garam}

Berdasarkan hasil kajian terhadap petani garam rakyat di Desa Bontokape dan Desa Donggobolo diketahui bahwa tingkat persentase umur sampai tahun 2011 berkisar 30-60 tahun ke atas. Lebih dari $50 \%$ berada pada usia produktif dan rataan umur petani pada usia 45 tahun. Kelompok umur tertinggi adalah kelompok 36-46 $(46,66 \%)$ dan kelompok umur terkecil adalah pada kelompok umur 58-68 (6,66\%).

Tingkat pendidikan petani masih sangat rendah, karena lebih dari $60 \%$ berpendidikan Sekolah Dasar (SD) dan Sekolah Menengah 
Pertanian (SMP). Rendahnya pendidikan ini disebabkan kondisi ekonomi masa lalu yang tidak mendukung untuk mendapatkan pendidikan yang lama. Selain itu, adanya anggapan hanya dengan tamat SD sudah bisa mencari atau mendapatkan uang. Seharusnya tingkat pendidikan yang rendah ini dapat diimbangi dengan pelatihan terhadap suatu inovasi baru, serta adanya penyuluhan produksi dan manajemen yang diberikan kepada petani garam rakyat.

Hasil kajian menunjukkan bahwa hampir semua petani garam rakyat sudah berkeluarga, dengan jumlah anggota keluarga 1-10 orang, tanggungan tersebut terdiri dari istri dan anak. Petani memiliki tanggungan cukup banyak. Dari rataan jumlah tanggungan petani Desa Bontokape dan Desa Donggobolo, jumlah tanggungannya 5 orang dalam keluarga. Kelompok tanggungan terbanyak pada kelompok tanggungan 3-4 orang $40 \%$ dan 5-6 orang 33,33\%. Hal ini menunjukan banyaknya jumlah tanggungan yang dimiliki mengandung indikasi jumlah pengeluaran untuk memenuhi kebutuhannya menjadi lebih besar dibandingkan dengan yang memiliki lebih sedikit tanggungan. Jumlah terkecil pada kelompok tanggungan 0-2 orang dan 9-10 orang, masingmasing $6,67 \%$.

Namun begitu tidak semua dari tanggungan tersebut menjadi tanggungan penuh, artinya tidak semua anggota keluarga memiliki usia produktif, tetapi sebagian dari anggota keluarga tersebut sudah bisa bekerja atau mendapatkan penghasilan. Dengan adanya anggota keluarga pada usia produktif, tenaga kerja menjadi tersedia dari dalam keluarga tersebut. Hal tersebut secara tidak langsung memiliki nilai tambah dari banyaknya anggota keluarga, sehingga membantu dalam kegiatan usaha garam keluarga, baik mulai dari penyiapan lahan, pengelolaan sampai panen dan pemasaran. Seperti yang banyak dilakukan oleh petani adalah menggunakan tenaga kerja keluarga. Namun pada umumnya, tidak semua anggota keluarga yang produktif ini dapat membantu secara penuh kegiatan usaha pegaraman keluarga, baik yang masih melanjutkan sekolah, mendapatkan pekerjaan dalam bidang lain, maupun yang tidak bekerja (pengangguran tersembunyi). Hal ini menunjukkan bahwa banyaknya anggota keluarga yang dimiliki petani tidak memberikan nilai tambah dalam usaha penggaraman. Adanya kesulitan dalam memenuhi kebutuhan hidup ini berdampak besar bagi kesejahteraan keluarga petani di daerah kajian.

Pengalaman kerja petani garam menunjukkan berapa lama petani bekerja pada bidang usaha penggaraman ini. Berdasarkan hasil kajian, pengalaman petani di Desa Bontokape dan Desa Donggobolo berkisar 10-40 tahun.

Dari jumlah rataan pengalaman petani dalam bertani garam, diperoleh pengalaman bertani masyarakat Desa Bontokape yang diwakili 5 petani dan Desa Donggobolo yang diwakili 10 petani adalah selama 20 tahun bekerja. Hal ini menunjukan bahwa pekerjaan bertani garam ini sudah lama dilakukan. Dengan hanya fokus terhadap satu pekerjaan, maka secara tidak langsung seorang petani garam akan memiliki keuletan dan ketelatenan dalam pekerjaannya, yang kemudian membentuk keahlian yang dimilikinya.

Petani garam rakyat yang menjadi contoh dalam kajian ini adalah petani garam yang sebagian besar mengelola lahan sendiri $(80 \%)$ dan sebagian kecil sebagai petani garam bagi hasil $(20 \%)$. Hal ini menunjukkan bahwa tingkat kepemilikan lahan petani masih sangat tinggi, akibat sisa warisan masa lalu.

\section{Analisis Produktivitas, Mutu, dan Kinerja Keuangan Usaha Petani Garam Rakyat}

\section{Produktivitas}

Hasil penelitian terhadap petani garam menurut produktivitas rataannya dimuat pada Tabel 3. Pada Tabel 3 terlihat bahwa luas lahan tidak diikuti dengan tingginya produktivitas, justru produktivitasnya rendah, dihasilkan oleh lahan lebih luas. Hasil analisis keragaman (analysis of variance atau Anova) menunjukkan bahwa luas lahan tidak berpengaruh terhadap produktivitas. Hal ini berarti Ho diterima, yaitu tidak terdapat perbedaan produktivitas pada luas lahan berbeda.

Tabel 3. Kelompok petani Garam menurut luas lahan dan produktivitas

\begin{tabular}{ccc}
\hline $\begin{array}{c}\text { K elompok } \\
\text { Luas Lahan (Ha) }\end{array}$ & $\begin{array}{c}\text { Rataan Luas } \\
\text { Lahan (Ha) }\end{array}$ & $\begin{array}{c}\text { Produktivitas } \\
\text { Rataan (Ton/Ha) }\end{array}$ \\
\hline$\geq 0,70$ & 0,85 & 8,12 \\
$0,31-0,69$ & 0,50 & 12,93 \\
$0,20-0,30$ & 0,23 & 33,33 \\
\hline
\end{tabular}


Tabel 4. Konsentrasi air laut dan \% kadar Garam per $10 \mathrm{ml}$ air laut milik petani garam

\begin{tabular}{llccc}
\hline & & \multicolumn{3}{c}{ Konsentrasi Air Laut } \\
\cline { 3 - 5 } No. & \multicolumn{1}{c}{ Petani Garam } & $\begin{array}{c}\text { Luas Lahan } \\
\text { Ha. }\end{array}$ & $\begin{array}{c}\text { oBe (Derajat kepekatan } \\
\text { suatu larutan) }\end{array}$ & $\begin{array}{c}\text { \% Kadar Garam Total } \\
\text { per 10 ml air contoh }\end{array}$ \\
\hline 1. & H.Yasin - Kec. Woha & 1,00 & 27 & 35,71 \\
2. & Saiful - Kec. Woha & 0,90 & 25 & 35,40 \\
3. & H.M Ali - Kec. Woha & 0,70 & 26 & 35,54 \\
4. & Usman - Kec. Woha & 0,65 & 25 & 36,08 \\
5. & Ahmad - Kec. Bolo & 0,53 & 27 & 39,48 \\
6. & Ismail - Kec. Woha & 0,50 & 16 & 19,47 \\
7. & Rudi - Kec. Bolo & 0,35 & 25 & 27,18 \\
8. & Mansur - Kec. Bolo & 0,30 & 24 & 35,86 \\
9. & Yusuf - Kec. Bolo & 0,20 & 27 & 35,41 \\
10. & H. Samsul - Kec. Bolo & 0,20 & 27 & 39,27 \\
\hline
\end{tabular}

Sumber: Hasil survei, dan Lab. Uji Stasiun Karantina Ikan Kelas II M Salahudin Bima, 2011.

Dari pengamatan di lokasi, ternyata yang lebih berpengaruh terhadap tinggi rendahnya produktivitas usaha petani garam di Desa Bontokape Kecamatan Bolo dan Desa Donggobolo Kecamatan Woha adalah mutu bahan baku air laut dan kesiapan lahan petani garam dalam memproduksi garam yang tepat waktu, yaitu pada saat di awal musim garam di Kabupaten Bima.

Pada umumnya, petani garam tidak siap pada waktu musim garam datang disebabkan terlalu memaksakan panen ikan bandeng sesuai waktu panen. Pada umumnya petani garam di Desa Bontokape Kecamatan Bolo dan Desa Donggobolo Kecamatan Woha menganut sistem Polikultur. Produktivitas rataan di Desa Bontokape Kecamatan Bolo adalah 35,55 Ton/Hektar. Produktivitas rataan di Desa Donggobolo Kecamatan Woha adalah 5,28 Ton/Hektar.

\section{Mutu}

Mutu garam rakyat yang baik banyak ditentukan oleh mutu air laut, karena berpengaruh terhadap proses penguapan larutan garam dan kristalisasi partikel-partikel garam. Air laut yang rataan sudah dua hari didiamkan pada 10 kolam pemekatan milik 10 petani garam dari 15 petani garam menjadi contoh kajian, dengan dua cara pengamatan, secara teknis dan analisis.

\section{a. Konsentrasi dan kadar garam air laut}

Pengamatan secara teknis dilakukan pada air laut yang telah didiamkan di kolam pemekatan selama dua hari dengan alat pengukur yang telah ditentukan, yaitu dengan Baume meter. Dalam hal ini yang diukur adalah konsentrasi air laut, standar derajat kepekatan air laut yang baik untuk pengkristalan menurut survei adalah $25^{\circ} \mathrm{Be}-29^{\circ} \mathrm{Be}$ dan persentase kadar garam (Tabel 4).
Berdasarkan hasil penelitian yang dilakukan diketahui bahwa kadar garam rataan berdasarkan data pada Tabel 4 dimuat pada Tabel 5.

Tabel 5. Kelompok petani garam menurut luas lahan dan kadar garam

\begin{tabular}{cccc}
\hline Kelompok & $\begin{array}{c}\text { Luas } \\
\text { Lahan (Ha) }\end{array}$ & $\begin{array}{c}\text { Rataan Luas } \\
\text { Lahan (Ha) }\end{array}$ & $\begin{array}{c}\text { Kadar } \\
\text { Garam } \\
\text { Rataan (\%) }\end{array}$ \\
\hline 1 & $\geq 0,70$ & 0,85 & 35,55 \\
2 & $0,31-0,69$ & 0,50 & 34,24 \\
3 & $0,20-0,30$ & 0,23 & 36,84 \\
\hline
\end{tabular}

Dari Tabel 5 terlihat bahwa tinggi atau rendahnya luas lahan tidak diikuti dengan perbedaan nyata terhadap kandungan kadar garamnya. Hasil analisis keragaman menunjukkan bahwa luas lahan tidak berpengaruh terhadap kadar garam, berarti Ho diterima, yaitu tidak terdapat perbedaan kadar garam per $10 \mathrm{ml}$ air laut pada luas lahan berbeda.

Dari pengamatan di lokasi diketahui bahwa hal ini disebabkan oleh sumber bahan baku diambil dari tempat yang sama, yaitu Teluk Bima dan ternyata yang lebih berpengaruh terhadap tinggi rendahnya kadar garam petani garam di Desa Bontokape Kecamatan Bolo dan Desa Donggobolo Kecamatan Woha adalah cara mengolah lahan tambak garam dengan baik. Misal lahan tambak garam yang sebelumya digunakan sebagai lahan tambak ikan bandeng harus benar-benar dibersihkan dari lumut, galengangalengan pada lahan tambak harus baik, sehingga air laut dengan konsentrasi ${ }^{\circ} \mathrm{Be}$ sudah baik dan siap untuk dikristalkan tidak 
rusak karena bocoran air tawar melalui galengan dari tambak di sebelah (mungkin masih bertambak ikan bandeng).

\section{b. Analisis fisika dan kimia air laut}

Hasil pengamatan secara analisis dengan fisika dan kimia sebagai parameter ujinya di laboratorium uji Stasiun Karantina Ikan Kelas II M. Salahudin Bima dimuat pada Tabel 6. Gambaran Mutu garam rakyat yang dihasilkan oleh petani garam rakyat, di ambil dari 3 petani garam yang memiliki luas lahan tambak berbeda, 1 petani garam di Desa Bontokape Kecamatan Bolo dan 2 petani garam di Desa Donggobolo Kecamatan Woha dengan pengujian secara visual dan analisis seperti dimuat pada Tabel 7.
Dari Tabel 15, dapat dilihat bahwa hasil uji laboratorium kadar $\mathrm{NaCl}$ garam tiga petani dari 15 petani garam adalah 78,71\%-91,35\%. Dari Tabel 15 terlihat bahwa kadar garam yang dihasilkan petani di Desa Donggobolo Kecamatan Woha lebih tinggi dibandingkan kadar garam yang dihasilkan petani di Desa Bontokape Kecamatan Bolo. Dengan demikian, saat ini petani garam di Desa Bontokape dan Desa Donggobolo belum mampu menghasilkan mutu garam yang memenuhi Standar Nasional Indonesia (SNI) dan tidak dapat bersaing dengan garam impor. Mutu garam yang dihasilkan oleh petani garam di Desa Bontokape dan Desa Donggobolo memiliki kadar $\mathrm{NaCl}$ di bawah 94\%. Garam konsumsi

Tabel 6. Hasil analisa mutu contoh air laut

\begin{tabular}{|c|c|c|c|c|c|c|c|c|c|}
\hline \multirow{3}{*}{$\begin{array}{l}\text { Nama Petani } \\
\text { Garam }\end{array}$} & \multirow{3}{*}{$\begin{array}{l}\text { Lokasi Desa, } \\
\text { Keca matan }\end{array}$} & \multicolumn{2}{|c|}{ FISIKA } & \multicolumn{6}{|c|}{ KIMIA } \\
\hline & & Suhu & TDS & DO & 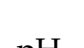 & Salinitas & $\mathrm{Fe}$ & $\mathrm{Na}_{2} \mathrm{SO}_{3}$ & $\mathrm{Cl}$ \\
\hline & & $\left({ }^{\circ} \mathrm{C}\right)$ & (ppm) & $(\mathrm{mg} / \mathrm{I})$ & pH & $(\mathrm{ppt})$ & $(\mathrm{ppm})$ & $(\mathrm{ppm})$ & $(\mathrm{ppm})$ \\
\hline 1. Ahmad & Bonto kape, Bolo & 28,75 & 60 & 0,43 & 7,23 & 70 & 0 & 4 & 0 \\
\hline 2. Yusuf & Bonto kape, Bolo & 28,02 & 60 & 0,45 & 7,39 & 70 & 0 & 8 & 0 \\
\hline 3. Mansur & Bonto kape, Bolo & 28,19 & 60 & 0,43 & 7,31 & 70 & 3,75 & 10 & 0 \\
\hline 4. H.Samsul & Bonto kape, Bolo & 28,01 & 60 & 0,46 & 7,28 & 70 & 3,75 & 10 & 0 \\
\hline 5. Rudi & Bonto kape, Bolo & 28,52 & 60 & 0,43 & 7,47 & 70 & 0 & 2 & 0,5 \\
\hline 6. H.Yasin & Donggobolo, Woha & 28,44 & 60 & 0,40 & 7,48 & 70 & 0 & 8 & 0,5 \\
\hline 7. Saiful & Donggobolo, Woha & 28,34 & 60 & 0,46 & 7,56 & 70 & 0 & 6 & 1,0 \\
\hline 8. Ismail & Donggobolo, Woha & 28,04 & 60 & 0,41 & 8,03 & 70 & 0 & 6 & 2,5 \\
\hline 9. Usman & Donggobolo, Woha & 28,55 & 60 & 0,41 & 7,55 & 70 & 0 & 6 & 0,5 \\
\hline 10. H. M Ali & Donggobolo, Woha & 28,59 & 60 & 0,43 & 7,47 & 70 & 0 & 6 & 0,5 \\
\hline
\end{tabular}

Sumber: Laboratorium Uji Stasiun Karantina Ikan Kelas II M Salahudin Bima.

\section{Keterangan:}

1. Suhu menunjukkan derajat panas benda. diukur dengan termometer Celsius

2. TDS (Total Dissolve Solid) adalah jumlah zat padat yang terlarut dalam air/ukuran tingkat kekeruhan air, yang dinyatakan dalam Part Per Million (PPM) DO (Dissolved Oxygen), yang merupakan kadar oksigen terlarut dalam milligram per Oksigen (mg/I)

3. $\mathbf{p H}$ adalah derajat keasaman yang digunakan untuk menyatakan tingkat keasaman atau kebasaan yang dimiliki oleh suatu larutan.

4. Salinitas adalah tingkat keasinan atau kadar garam terlarut dalam air, yang dinyatakan dalam "bagian perseribu" (parts per thousand atau ppt).

5. Fe (Ferrum) adalah unsur besi

6. $\mathrm{Na}_{2} \mathrm{SO}_{3}$ adalah Natrium sulfit adalah natrium yang dapat larut dalam air

7. $\mathbf{C l}$ (Klorin) adalah unsur pembentuk garam

Tabel 7. Hasil pengujian mutu garam rakyat

\begin{tabular}{lccccc}
\hline $\begin{array}{c}\text { Nama Petani } \\
\text { Garam }\end{array}$ & Luas Lahan (Ha) & $\begin{array}{c}\text { Lokasi Desa, } \\
\text { Kecamatan }\end{array}$ & $\begin{array}{c}\text { Kadar NaCl } \\
(\%)\end{array}$ & Warna & $\begin{array}{c}\text { Diameter } \\
\text { Kristal (mm) }\end{array}$ \\
\hline Ridwan & 0,20 & Donggobolo, Woha & 91,35 & Putih Keruh & $<5$ \\
H. Yasin & 1,00 & Donggobolo, Woha & 82,48 & Putih Keruh & $<5$ \\
Ahmad & 0,53 & Bontokape, Bolo & 78,71 & Putih Keruh & $<5$ \\
\hline
\end{tabular}

Sumber: Balai Pengujian dan Identifikasi Barang Jakarta. 
harus memenuhi kadar $\mathrm{NaCl}$ tidak kurang dari $94 \%$, untuk garam kelas dua, tidak boleh rendah dari $97 \%$ untuk garam kelas satu dan garam industri di atas $99 \%$.

\section{Kinerja Keuangan Usaha Petani Garam Rakyat 1. Pendapatan}

Harga produksi garam di Kabupaten Bima berbeda-beda, karena dipengaruhi oleh cuaca dan musim garam. Padahal garam bukan merupakan komoditas yang mudah busuk, tetapi dapat disimpan dalam jangka waktu cukup lama, sehingga seharusnya harga garam relatif lebih stabil dibandingkan harga komoditas pertanian. Selain dari itu, petani garam di Kabupaten Bima khususnya di Desa Bontokape dan Desa Donggobolo tidak bisa menaikkan posisi tawar harga akibat ketidaktahuan mengenai mutu garam dan tidak banyaknya pembeli tetap. Masalah lain yang memengaruhi harga garam rendah adalah para petani garam di Desa Bontokape maupun Desa Donggobolo sebagian besar tidak memiliki tempat penyimpanan garam yang layak. Penerimaan usaha petani garam adalah perkalian antara produksi yang diperoleh dengan harga jual.

Dalam penelitian ini dihitung penerimaan usaha garam rakyat dengan memperhatikan: (1) proses produksi usaha garam yang dapat dipanen beberapa kali, sehingga tidak semua produksi garam antar petani dapat dipanen secara serentak, artinya dalam satu bulan produksi tiap petani berbeda-beda; (2) Produksi mungkin dijual dalam beberapa kali dengan harga jual berbeda-beda. Untuk mempermudah perhitungan dibuat data frekuensi produksi dan data frekuensi penjualan terhadap 15 petani yang ada di Desa Donggobolo dan Desa Bontokape per 1 Juni sampai dengan 14 Agustus 2011.

Pada kenyataannya, 4 dari 15 petani garam sampai pertengahan bulan Agustus, memiliki lahan hasil produksi sangat sedikit, (kurang dari $10 \mathrm{Kg}$ ). Hal ini disebabkan keterlambatan petani garam dalam penyiapan lahan tambak garam, serta mutu bahan baku yang kurang baik dan 1 petani garam pada lahan tambaknya, dimana hasil produksi 350 $\mathrm{kg}$, tetapi hingga pertengahan bulan Agustus hasil produksinya belum terjual, sehingga perhitungan penerimaan hanya 10 petani garam (Tabel 8).

Per hektar usaha petani garam dari Tabel 8 menunjukkan penerimaan tertinggi berturut-turut diperoleh oleh $\mathrm{H}$. Samsul (Rp43.300.000), Yusuf (Rp20.250.000) dan Ahmad (Rp15.924. 528). Ke semua petani garam dengan penerimaan tertinggi tersebut terdapat di Desa Bontokape Kecamatan Bolo. Hal ini mungkin disebabkan faktor kesiapan lahan petani garam di Desa Bontokape dalam memproduksi garam tepat waktu, yaitu pada saat bulan Juni di awal musim kemarau tahun 2011 di Kabupaten Bima dan faktor lokasi

Tabel 8. Total perhitungan penerimaan usaha petani garam per hektar Desa Donggobolo Kecamatan Woha dan Desa Bontokape Kecamatan Bolo per 1 Juni-14 Agustus 2011

\begin{tabular}{llcr}
\hline \multicolumn{1}{c}{ Petani Garam } & Lokasi Desa, Kecamatan & $\begin{array}{c}\text { Luas Lahan } \\
(\mathrm{Ha})\end{array}$ & TR/Ha (Rp) \\
\hline Kelompok 1 & & & \\
1. H. Yasin & Donggobolo, Woha & 1,00 & 2.695 .000 \\
2. Saiful & Donggobolo, Woha & 0,90 & 1.390 .000 \\
3. H. M Ali & Donggobolo, Woha & 0,70 & 5.664 .286 \\
\hline Kelompok 2 & & & \\
1. Usman & Donggobolo, Woha & 0,65 & \\
2. Ahmad & Bontokape, Bolo & 0,53 & \\
3. Rudi & Bontokape, Bolo & 0,35 & 8.924 .528 \\
\hline Kelompok 3 & & & 8.400 .000 \\
1. Mansur & Bontokape, Bolo & 0,30 & 43.300 .000 \\
2. H. Samsul & Bontokape, Bolo & 0,20 & 20.250 .000 \\
3. Yusuf & Bontokape, Bolo & 0,20 & 265.000 \\
4. Ridwan & Donggobolo, Woha & 0,20 & \\
\hline
\end{tabular}

Sumber: Hasil survei, dianalisis penyusun, 2011. 

bahan baku (air laut) di Desa Bontokape yang berada di pertengahan Teluk Bima di bandingkan lokasi bahan baku di Desa Donggobolo yang berada tepat di bawah Teluk Bima. Pengeluaran usaha petani garam berdasarkan luas lahan per hektar sampai dengan pertengahan bulan Agustus dapat dilihat pada Tabel 9.

Hasil perhitungan pendapatan 10 petani yang ada di Desa Donggobolo Kecamatan Woha dan Desa Bontokape Kecamatan Bolo per 1 Juni sampai dengan 14 Agustus 2011, ditampilkan pada Tabel 10.

Tabel 9. Pengeluaran per hektar usaha petani garam per 1 Juni s/d 14 Agustus Tahun 2011

\begin{tabular}{|c|c|c|}
\hline Petani Garam & $\begin{array}{c}\text { Luas Lahan } \\
(\mathrm{Ha})\end{array}$ & $\begin{array}{c}\mathrm{TC} / \mathrm{Ha} \\
(\mathrm{Rp})\end{array}$ \\
\hline \multicolumn{3}{|l|}{ Kelompok 1} \\
\hline 1. H.Yasin Kec.Woha & 1,00 & 763.000 \\
\hline 2. Saiful Kec.Woha & 0,90 & 1.512 .778 \\
\hline 3. H.M Ali Kec.Woha & 0,70 & 1.077.143 \\
\hline \multicolumn{3}{|l|}{ Kelompok 2} \\
\hline 1. Usman Kec.Woha & 0,65 & 1.173 .077 \\
\hline Ahmad Kec.Bolo & 0,53 & 1.132 .075 \\
\hline 3. Rudi Kec.Bolo & 0,35 & 5.957 .143 \\
\hline \multicolumn{3}{|l|}{ Kelompok 3} \\
\hline 1. Mansur Kec.Bolo & 0,30 & 1.666 .667 \\
\hline H. Samsul Kec.Bolo & 0,20 & 2.500 .000 \\
\hline Yusuf Kec.Bolo & 0,20 & 2.500 .000 \\
\hline 4. Ridwan Kec.Woha & 0,20 & 2.590 .000 \\
\hline
\end{tabular}

Sumber: Hasil survei, dianalisis penyusun, 2011.

Dari Tabel 10, terlihat bahwa petani garam dengan perolehan pendapatan tertinggi per $\mathrm{Ha}$ adalah H. Samsul (Rp40.800.000), Yusuf (Rp17.750.000) dan Ahmad (Rp14.792.453) yang kesemuanya berlokasi di Desa Bontokape Kecamatan Bolo, sedangkan beberapa petani garam di Desa Donggobolo Kecamatan Woha bahkan merugi. Fakta ini menguatkan bahwa faktor lokasi dan kesiapan petani mengusahakan garam sangat penting. Pendapatan rataan petani garam menurut kelompok luas lahan terlihat pada Tabel 11. Dari Tabel 11 terlihat bahwa peningkatan luas lahan tidak diikuti dengan tingginya pendapatan dan menunjukkan bahwa petani garam dengan lahan semakin luas memperoleh pendapatan lebih rendah.

Hasil analisis keragaman dapat diketahui bahwa luas lahan tidak berpengaruh terhadap pendapatan, berarti Ho diterima, yaitu tidak terdapat perbedaan pendapatan pada luas lahan berbeda. Dari pengamatan di lokasi ternyata yang lebih berpengaruh terhadap tinggi rendahnya pendapatan usaha petani garam di Desa Bontokape dan Desa Donggobolo adalah mutu bahan bakunya, yaitu air laut dilihat dari cepatnya air laut tersebut menjadi kristal garam dan kesiapan lahan petani garam dalam memproduksi garam tepat waktu. Dalam hal ini, petani garam di Desa Bontokape, Kecamatan Bolo, kesiapan lahan pada waktu tepat, yaitu pada bulan Juni (awal musim kemarau). Pendapatan rataan per hektar petani garam dari 5 petani garam di Desa Donggobolo Kecamatan Woha adalah Rp595,965, sedangkan pendapatan rataan per hektar petani garam di Desa Bontokape

Tabel 10. Hasil perhitungan pendapatan per hektar usaha petani garam Desa Donggobolo Kecamatan Woha dan Desa Bontokape Kecamatan Bolo Per 1 Juni s/d 14 Agustus Tahun 2011

\begin{tabular}{lcrrr}
\hline \multicolumn{1}{c}{ Petani Garam } & $\begin{array}{c}\text { Luas Lahan } \\
\text { (Hektar) }\end{array}$ & $\begin{array}{r}\text { Penerimaan/ } \\
\text { Hektar (Rp) }\end{array}$ & Biaya/Hektar (Rp) & $\begin{array}{r}\text { Pendapatan/ } \\
\text { Hektar (Rp) }\end{array}$ \\
\hline Kelompok 1 & & & & \\
1. H. Yasin Kec. Woha & 1,00 & 2.695 .000 & 763.000 & 1.932 .000 \\
2. Saiful Kec. Woha & 0,90 & 1.390 .000 & 1.512 .778 & $(122.778)$ \\
3. H. M Ali Kec. Woha & 0,70 & 5.664 .286 & 1.077 .143 & 4.587 .143 \\
\hline Kelompok 2 & & & & \\
1. Usman Kec. Woha & 0,65 & 81,538 & 1.173 .077 & $(1.091 .538)$ \\
2. Ahmad Kec. Bolo & 0,53 & 15.924 .528 & 1.132 .075 & 14.792 .453 \\
3. Rudi Kec. Bolo & 0,35 & 8.485 .714 & 5.957 .143 & 2.528 .571 \\
\hline Kelompok 3 & & & & \\
1. Mansur Kec. Bolo & 0,30 & 8.400 .000 & 1.666 .667 & 6.733 .333 \\
2. H. Samsul Kec. Bolo & 0,20 & 43.300 .000 & 2.500 .000 & 40.800 .000 \\
3. Yusuf Kec. Bolo & 0,20 & 20.250 .000 & 2.500 .000 & 17.750 .000 \\
4. Ridwan Kec. Woha & 0,20 & 265.000 & $2.590,000$ & $(2.325 .000)$ \\
\hline
\end{tabular}

Sumber: Hasil survei, dianalisis penyusun, 2011. 
Kecamatan Bolo dari 5 petani garam adalah Rp16.520.871. Perbedaan pendapatan rataan per hektar petani garam di kedua lokasi tersebut sangat jauh.

Tabel11. Kelompok Petani Garam Menurut Luas Lahan dan Pendapatan

\begin{tabular}{cccc}
\hline Kelompok & $\begin{array}{c}\text { Luas Lahan } \\
(\mathrm{Ha})\end{array}$ & $\begin{array}{c}\text { Rataan } \\
\text { Luas Lahan } \\
(\mathrm{Ha})\end{array}$ & $\begin{array}{c}\text { Pendapatan } \\
\text { Rataan (Rp) }\end{array}$ \\
\hline 1 & $\geq 0,70$ & 0,85 & 2.132 .121 \\
2 & $0,31-0,69$ & 0,50 & 5.409 .828 \\
3 & $0,20-0,30$ & 0,23 & 15.738 .583 \\
\hline
\end{tabular}

\section{2. $\mathrm{R} / \mathrm{C}$ ratio Usaha Garam Rakyat}

Analisis Return Cost (R/C) ratio merupakan perbandingan (ratio atau nisbah) antara penerimaan (revenue) dan biaya (cost) dengan kriteria keputusan:

1. $R / C>1$, Usaha petani garam rakyat untung

2. $\mathrm{R} / \mathrm{C}<1$, Usaha petani garam rakyat rugi

3. $\mathrm{R} / \mathrm{C}=1$, Usaha petani garam rakyat impas (tidak untung/tidak rugi)

Hasil perhitungan $\mathrm{R} / \mathrm{C}$ ratio ditampilkan pada Tabel 12.

Dari Tabel 12, terlihat bahwa dari 10 petani garam, 7 petani garam dengan $\mathrm{R} / \mathrm{C}$ ratio usaha memiliki angka $>1$, sehingga telah meraih untung. Petani garam yang R/C ratio usahanya di bawah angka 1 sebanyak 3 orang yang kesemuanya berlokasi di Desa Donggobolo Kecamatan Woha. $\mathrm{R} / \mathrm{C}$ ratio rataan petani garam menurut kelompok luas lahan dimuat pada Tabel 13.
Tabel 13. Kelompok petani garam menurut luas lahan dan $\mathrm{R} / \mathrm{C}$ ratio

\begin{tabular}{cccr}
\hline Kelompok & $\begin{array}{c}\text { Luas Lahan } \\
(\mathrm{Ha})\end{array}$ & $\begin{array}{c}\text { Rataan } \\
\text { Luas } \\
\text { Lahan (Ha) }\end{array}$ & $\begin{array}{c}\text { R/C ratio } \\
\text { Rataan }(\%)\end{array}$ \\
\hline 1 & $\geq 0,70$ & 0,85 & 3.2367 \\
2 & $0,31-0,69$ & 0,50 & 5.2333 \\
3 & $0,20-0,30$ & 0,23 & 10.1533 \\
\hline
\end{tabular}

Dari Tabel 13 terlihat bahwa tingginya luas lahan tidak diikuti dengan tingginya R/C ratio. Hasil analisis keragaman, diketahui bahwa luas lahan tidak berpengaruh terhadap $\mathrm{R} / \mathrm{C}$ ratio, berarti Ho diterima, yaitu tidak terdapat perbedaan $\mathrm{R} / \mathrm{C}$ ratio pada luas lahan berbeda. Dari pengamatan di lokasi pada umumnya (7 petani garam) menunjukan bahwa $\mathrm{R} / \mathrm{C}$ ratio lebih besar dari 1 dan hanya 3 petani garam dengan $\mathrm{R} / \mathrm{C}$ ratio kurang dari 1, berlokasi di Desa Donggobolo Kecamatan Woha.

\section{KESIMPULAN}

Pendapatan per hektar petani garam di Desa Bontokape Kecamatan Bolo dan Desa Donggobolo Kecamatan Woha Rp2.325.000Rp40.800.000, tetapi pendapatan per hektar petani garam di Desa Bontokape Kecamatan Bolo jauh lebih tinggi dibandingkan petani garam di Desa Donggobolo Kecamatan Woha. Dalam hal ini, dari 10 petani garam yang diteliti di kedua lokasi, ada 7 petani garam yang $\mathrm{R} / \mathrm{C}$ ratio usahanya di atas 1 (untung) dan 3 lainnya di bawah 1 (rugi).

Tabel 12 . R/C Ratio usaha petani garam per 1 Juni-14 Agustus 2011

\begin{tabular}{lcrrrc}
\hline Petani Garam & $\begin{array}{c}\text { Luas Lahan } \\
(\mathrm{Ha})\end{array}$ & $\begin{array}{c}\text { Penerimaan } \\
(\mathrm{Rp})\end{array}$ & Biaya (Rp) & Hasil Analisis & Kesimpulan \\
\hline 1. H. Yasin & 1,00 & 2.695 .000 & 763.000 & 3,53 & Untung \\
2. Saiful & 0,90 & 1.390 .000 & 1.512 .778 & 0,92 & Rugi \\
3. H. M Ali & 0,70 & 5.664 .286 & 1.077 .143 & 5,26 & Untung \\
4. Usman & 0,65 & 81,538 & 1.173 .077 & 0,07 & Rugi \\
5. Ahmad & 0,53 & 15.924 .528 & 1.132 .075 & 14,07 & Untung \\
6. Rudi & 0,35 & 8.485 .714 & 5.957 .143 & 1,42 & Untung \\
7. Mansur & 0,30 & 8.400 .000 & 1.666 .667 & 5,04 & Untung \\
8. H. Samsul & 0,20 & 43.300 .000 & 2.500 .000 & 17,32 & Untung \\
9. Yusuf & 0,20 & 20.250 .000 & 2.500 .000 & 8,10 & Untung \\
10. Ridwan & 0,20 & 265.000 & $2.590,000$ & 0,10 & Rugi \\
\hline
\end{tabular}

Sumber: Hasil survei, dianalisis penyusun, 2011. 

Produktivitas rataan petani garam di Desa Bontokape Kecamatan Bolo dan Desa Donggobolo Kecamatan Woha Kabupaten Bima Nusa Tenggara Barat 8,12-33,33 ton/hektar. Mutu garam rakyat dilihat dari aspek kadar garam 35,55$36,48 \%$, menghasilkan garam dengan kadar $\mathrm{NaCl}$ $84,14 \%$, warna putih keruh dan diameter kristalnya $<5 \mathrm{~mm}$, sehingga belum memenuhi SNI.

\section{DAFTAR PUSTAKA}

Fahmi, I. 2010. Manajemen Kinerja Teori dan Aplikasi. Alfabeta, Bandung.

Haryatno. 2012. Kajian Strategi Adaptasi Budaya Petani Garam. Jurnal Komunitas; 4(2): 191199.
Ihsannudin. 2012. Pemberdayaan Petani Penggarap Garam Melalui Kebijakan Berbasis Pertanahan. Jurnal Pemberdayaan Mahasiswa dan Masyarakat, LPPM Universitas Sebelas Maret Surakarta; 2(1): 1-11.

Kadarisman, D. 2006. Sistem Jaminan Mutu Industri Pangan. IPB Press, Bogor.

(KKP) Kementerian Kelautan dan Perikanan, Dirjen KP3K. 2010. Pedoman Pengembangan Jasa Kelautan. Direktorat Pesisir dan Lautan, Jakarta.

Kementerian Kelautan dan Perikanan, Dirjen KP3K. 2011. Pemberdayaan Usaha Garam Rakyat. Direktorat PMP, Jakarta.

Moehar, D. 2005. Metode Penelitian Sosial Ekonomi. PT Bumi Aksara, Jakarta.

Supranto. 2002. Metode Riset Aplikasinya Dalam Pemasaran. Rineka Cipta, Jakarta. 